\title{
STUDY ON INSPECTION OF THE PUTATIVE HYBRIDS BETWEEN TRACK-LACKING WILD MALE GAUR (BOS GAURUS) AND DOMESTIC FEMALE COW (BOS TAURUS) IN PHUOC BINH NATIONAL PARK, VIETNAM
}

\author{
Le Hoang Duc ${ }^{1,2}$, Pham Thanh Tung ${ }^{1,2}$, Nguyen Trung $\mathrm{Nam}^{1,2}$, Chu Hoang $\mathrm{Ha}^{1,2}$, Le Xuan Tham ${ }^{3}$, Le \\ Van Son ${ }^{1,2, 凶}$ \\ ${ }^{1}$ Institute of Biotechnology, Vietnam Academy of Science and Technology \\ ${ }^{2}$ Graduate University of Science and Technology, Vietnam Academy of Science and Technology \\ ${ }^{3}$ Lam Dong Department of Science and Technology, Lam Dong, Vietnam
}

To whom correspondence should be addressed. E-mail: levanson@ibt.ac.vn

Received: 23.11 .2017

Accepted: 28.12.2017

\section{SUMMARY}

\begin{abstract}
Hybridization between wild and domestic bovine occurs widely due to the overlapping of the natural habitat of the wild and human farm animals. Due to the loss of habitat, the number of wild gaur (Bos gaurus) in Vietnam was in serious decline. Since 2009, a male wild gaur (Bos gaurus) has appeared and incorporated with female domestic cows (Bos taurus) in buffer zone Phuoc Binh National Park, on the border with Lam Dong and Ninh Thuan provinces. Then, several calves were born that carried some traits of wild gaur including physical characteristics and behaviors. These calves were supposed to be offspring between wild gaur and domestic cows. In previous study, the karyotypes of putative calves were identified with $2 \mathrm{n}=58$ and nonhomologous chromosome 28 and 29 in these hybrids. In this study, we characterized the putative hybrids between track-lacking Bos gaurus and Bos taurus for breeding and preservation using Cytochrome $b$ analysis, microsatellites and a novel marker growth hormone factor 1 (POU1F1). Cytochrome $b$ analysis indicated the maternal lineage of the putative hybrids, with $100 \%$ nucleotide sequence identity. Microsatellite $B M 861$ and sequence of $Z F Y$ gene region reveal Bos taurus chromosome $\mathrm{Y}$ origin was among the male putative hybrids. Importantly, the analysis of POU1F1 gene sequence on 1 chromosome showed efficacy in determining both Bos gaurus and Bos taurus lineage in the putative hybrids. The karyotyping results were confirmed by molecular analysis and our results provide a feasible way for detecting the putative hybrids between wild and domestic cattle in case of lacking the wild trace.
\end{abstract}

Keywords: Interspecific hybrids, molecular makers, paternal lineage, maternal lineage

\section{INTRODUCTION}

Interspecific hybridization happens to two closely related species that share an overlapping habitat or via human interference during captive inbreeding. However, they also run a high risk of being sterilized and fertility is often restricted to the homogametic (Forsdyke, 2000). This can be overcome by continuously backcrossing the hybrids with either father or mother. Hence, the hybrids of closely related species can be valuable in farming as a way to improve quality of local domestic cattle. For instance, yakows, a cross of yak (Bos grunniens) and taurine cattle (Felius, 1995); selembu, a cross of wild gaur (Bos gaurus) and zebu or the American beefalo, a cross of bison (Bison bison) and taurine cattle.

In Vietnam, the population of wild gaur (Bos gaurus) is poorly investigated and they are believed to decline in number due to loss of habitat. Since 2009, there has been observed that a lone male gaur migrated to the buffer zone of Phuoc Binh National Park and joined the local cattle herd for months and left without trace. After that, there appeared a number of newborn calves that carried unusual traits compared to other ordinary domestic cattle in consideration of physical characteristics and behaviors. These calves were putative to be hybrids between the lone male gaur (Bos taurus) and the local domestic cows (Bos taurus). Previous studies 
showed that in comparison with cattle (Bos taurus), gaur (Bos gaurus) did not carry chromosome 28 and 29. Additionally, the chromosomes 1 and 2 in gaur were submetacentric while those in cattle are metacentric (Basrur \& Moon, 1967). It was observed that in chromosomes 1 and 2 of the hybrids, one chromosome of each pair lack a short arm. Similar interspecific hybridizations were also found in Malaysia. In those cases, the hybrids carried karyotype $2 n=57,58,59$ or 60 (Mamat-Hamidi et al., 2009, 2012). This could be explained by Robersonian translocation that occurred during evolution of bovine species (Chaves et al., 2003, Kakampuy et al., 2007).

To verify the paternal and maternal linage of the putative hybrids, several methods were used, from karyotype analysis to genotype analysis. Previous studies showed that non-homologous chromosome 28 and 29 were also observed in these hybrids' karyotypes (Tran Que \& Pham Van Duy, 2014). To confirm the karyotyping results by molecular analysis, we used segment of mitochondrial Cytochrome $b$ to identify maternal species origin of the putative hybrids. Y chromosomal molecular marker including microsatellite $B M 861$ and $Z F Y$ were previously proved to be specific for gaur identification (Trung Thanh Nguyen et al., 2007; Verkaar et al., 2003).

A new maker used in this study is growth hormone factor POUIF1 or PIT1 coding gene. $P O U 1 F 1$ is a 291 amino acid protein with POU domain as DNA binding. POU1F1 has been proven to be critical transcription factor in expression of prolactin (PRL) and growth hormone $(\mathrm{GH})$ genes in anterior pituitary gland (Bona et al., 2004). This gene is localized in centromeric region of chromosome 1q21-22 (Woolard et al., 1999) and has potential for being a marker for genetic variation and yield traits (Renaville et al., 1997a).

In this study, we demonstrated the use of genotyping analysis and molecular markers including POU1F1 to detect the putative hybrids between track-lacking wild gaur (Bos gaurus) and domestic cow (Bos taurus).

\section{MATERIALS AND METHODS}

\section{Sampling}

Peripheral blood and tissue samples were collected from a domestic male cow (BN1) as control and a female cow (BN2) which is maternal relationship with the suspected hybrid named BL1 and the four putative hybrids including a male (BL1) and three females (BL2; BL3 and BL4) in Phuoc Binh National Park, Ninh Thuan province, Vietnam. The peripheral blood were mixed with Heparin for anti-coagulation. The blood samples were stored at 4 ${ }^{\circ} \mathrm{C}$ and the tissue samples were store at $-20{ }^{\circ} \mathrm{C}$ before use.

\section{DNA isolation from tissue}

Genomic DNA was isolated and purified from dry tissue and blood samples using QIAamp DNA mini kit (Qiagen, Germany) according to the manufacturer's instruction.

\section{Cytochrome b (Cyt b) analysis}

Primers used to amplify a $274 \mathrm{bp}$ long fragment of Cyt $b$ were: L15612f: CGATCAATYCCYAAYAAACTAGG and H15915r: TCTCCATTTCTGGTTTACAAGAC (Hassanin et al., 2006) to amplify a 274 bp long fragment. Procedure for PCR amplification of Cyt $b$ from genomic DNA was as follow: $25 \mu \mathrm{l}$ of reaction mixture containing $0.5 \mu 1$ genomic DNA (50 ng/ $\mu 1$ ), 1X PCR buffer (10 mM Tris- $\mathrm{HCl}, \mathrm{pH} 8.3,50 \mathrm{mM}$ $\mathrm{KCl}, 1.5 \mathrm{mM} \mathrm{MgCl}_{2}$ ), $1 \mathrm{mM}$ of dNTP mix, $10 \mathrm{pmol}$ of each primer and 1 unit of Taq polymerase (Thermo Scientific, Germany) was set in thermal condition of 4 minutes denaturation at $94{ }^{\circ} \mathrm{C}$, followed by 30 cycles of 45 seconds at $94{ }^{\circ} \mathrm{C} ; 45$ seconds at $56{ }^{\circ} \mathrm{C} ; 50$ seconds at $72{ }^{\circ} \mathrm{C}$ and eight minutes of final extension at $72{ }^{\circ} \mathrm{C}$, before cooling at $15{ }^{\circ} \mathrm{C}$. Results was obtained by $2 \%$ agarose electrophoresis and sequencing (using DNA sequencer ABI Prism 3100 Avant). Sequences then were aligned by ClustalW tool of Bioedit 7.0.5.3 (Hall et al., 1999).

Amplification of $B M 861, Z F Y$, and $P O U 1 F 1$ genes $Z F Y$ primers used were YF1: TCACTTTATTACTATGGTAACTG and YR1: CGAAAACCTTTACCACACTCTACA. Primers used to amplify BM861 were BM861F: TTGAGCCACCTGGAAAGC and BM861R: CAAGCGGTTGGTTCAGATG (Nguyen et al, 2007). POU1F1 gene: two sets of primer specific for species were used to amplify the intron 5 sequence of the gene. The primers for Bos gaurus sequence amplification were PG1F: AGAATGACTGTTTCTACTGTCGGT and PG1R: CTAAATATTAGTACTAACATTAAT. The 
primers for Bos taurus sequence amplification were PT1F: GTGTCATAATGTGTTGATTTATGT and PT1R: GTGTCATAATGTGTTGATTTATGT. PCR reaction was performed in PTC-100 thermal Cycler (MJ Research, USA) with the volume of $25 \mu 1$ reaction mixture containing $0.5 \mu 1$ genomic DNA (50 $\mathrm{ng} / \mu \mathrm{l}), 1 \mathrm{X}$ PCR buffer (10 mM Tris-HCl, pH 8.3, 50 $\mathrm{mM} \mathrm{KCl}, 1.5 \mathrm{mM} \mathrm{MgCl}_{2}$ ), $0.2 \mathrm{mM}$ of dNTPs mix, 10 pmol of each primer and 1 unit of Taq polymerase (Thermo Scientific, Germany); the thermal condition was as followed: 4 minutes denaturation at $94{ }^{\circ} \mathrm{C}$, followed by 30 cycles of 60 seconds at $94{ }^{\circ} \mathrm{C} ; 45$ seconds at $48{ }^{\circ} \mathrm{C}-60{ }^{\circ} \mathrm{C}$ (depend on primers); 45 seconds at $72{ }^{\circ} \mathrm{C}$ and seven minutes of final extension at $72{ }^{\circ} \mathrm{C}$, before cooling at $15{ }^{\circ} \mathrm{C}$. The PCR product was analyzed by SDSPAGE electrophoresis (6\% polyacrylamide) for BM861 and agarose $0.8 \%$. Then they were purified by High Pure PCR purification Kit (Roche, Germany) and then cloned into a cloning vector for sequencing. Sequencing was performed by DNA sequencer ABI Prism 3100 Avant. Data obtained was put in analysis using Bioedit 7.0.5.3 (Hall et al., 1999).

\section{RESULTS}

\section{Cytochrome $b$ analysis}

Cytochrome $b$ analysis was used to confirm maternal linage between the suspected hybrids and the domestic cows. In this study, a conserves sequence on Cyt $b$ was amplified by 303 bp long fragment of Cyt $b$ was amplified, sequenced and subsequently aligned with each other and known sequences. The alignment showed that all sequences obtained from the putative hybrids are $100 \%$ homologous with corresponding part of Bos taurus full sequence (KP143771.1) from GenBank (Data not shown). This indicates that the maternal origin of the putative hybrids is Bos taurus species.

\section{Y chromosomal marker analysis}

Both Zinc-finger protein $(Z F Y)$ and microsatellite $B M 861$ are localized on $\mathrm{Y}$ Bovine chromosome. Furthermore, highly polymorphism of $B M 861$ and $Z F Y$ in Bovine family can reveal species identities (Cui et al., 1998; Poloumienko, 2004 and Nguyen et al., 2007), thus, they were recruited to identify Bos gaurus origin as paternal linage in the genome of suspected male hybrids. Allele from both domestic and putative male calves were successfully amplified and observed on denatured polyacrylamide gel (Figure 1). The putative calf carried a $172 \mathrm{bp}$ long fragment while this in cattle calf is $156 \mathrm{bp}$. The alleles were sequenced and aligned and showed in figure 2. In comparison with cattle microsatellite, the putative calf contains a short stretch of 16 repeated GT at location 132 to 147 and two point mutations at location 58 and 60. Nucleotide sequences for microsatellites were deposited into GenBank with accession number KP890802 (Bos gaurus) and KP890803 (Bos taurus).

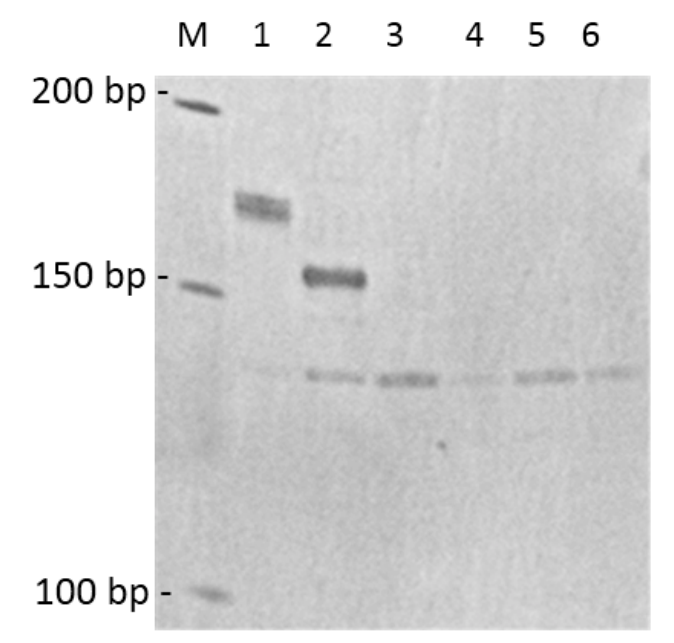

Figure 1. Alleles obtained from domestic calves (Bos taurus) and the putative calves were demonstrated on denatured polyacrylamide gel (6\%). M: marker $50 \mathrm{bp}$; 1: putative hybrid (male); 2: domestic cattle (male); 3-5: putative hybrid (female); 6: domestic cattle (female). 


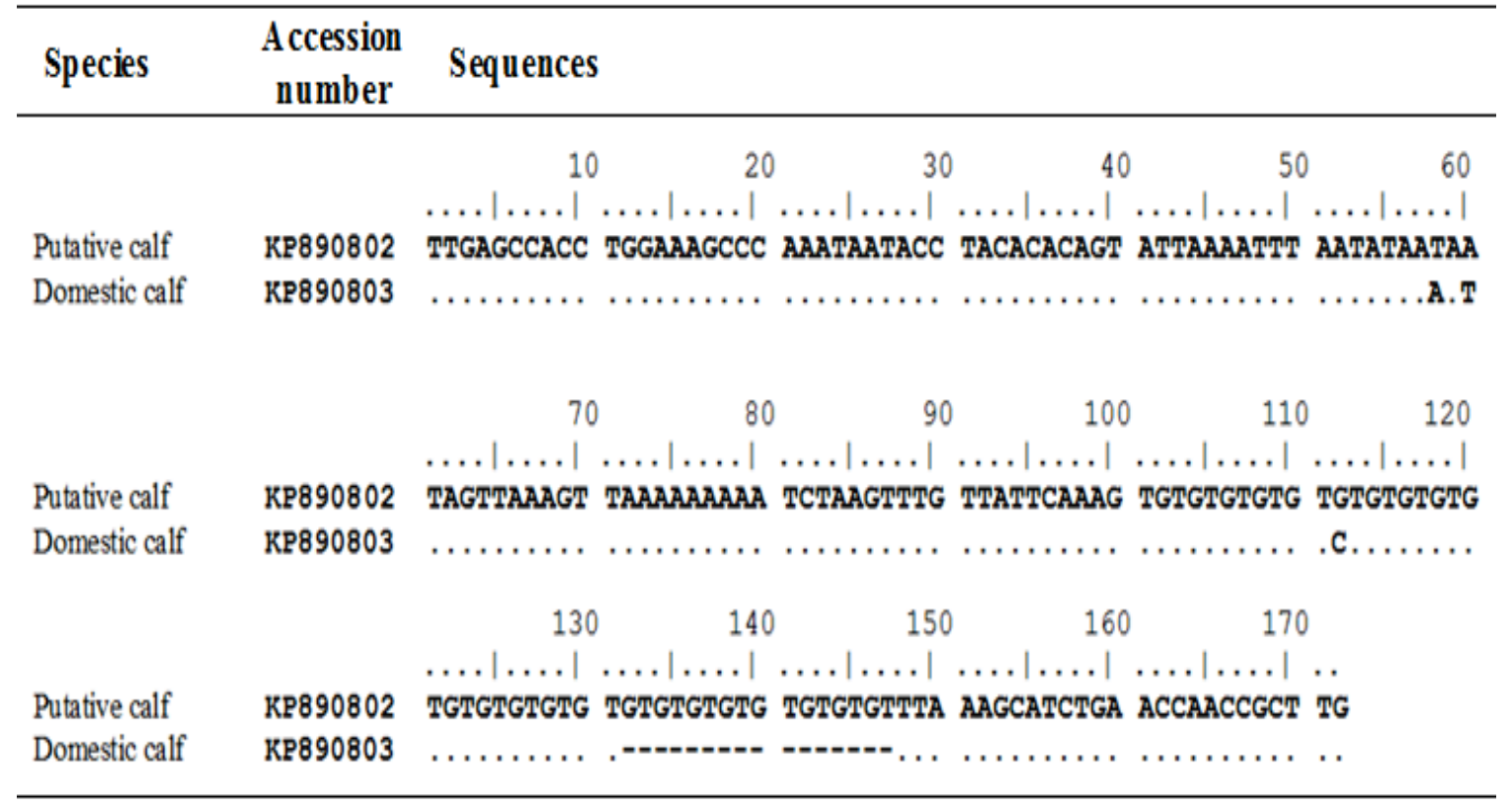

Figure 2. Alignment of $B M 861$ sequences obtained from domestic and putative calves. Dots indicate identical bases and dashes indicate insertions/deletions for optimal alignment.

A 592bp-long fragment of $Z F Y$ gene was amplified and analyzed by electrophoresis and sequencing. Figure 3 showed differences between the putative hybrids and the domestic cattle as well as Bos taurus ZFY sequence from GenBank (NT_182067). This gene fragment in wild gaur can be distinct by four point mutations at position 102 , 103, 263 and 375. BLAST search results showed that $Z F Y$ fragment obtained from the putative hybrid is $99 \%$ homologous with Bos gaurus sequence while those obtained from the domestic calves were $99 \%$ homologous with Bos taurus.

\section{POU1F1 gene analysis}

The primers were designed to amplify $675 \mathrm{bp}$ long interested fragments POU1F1 gene in Bos taurus and Bos gaurus. In the putative hybrids, both fragments of Bos taurus and Bos gaurus were amplified while in the domestic calves only the
POU1F1 fragment of Bos taurus was amplified from genomic DNA. Sequence alignment of these fragments was illustrated in figure 4. It can be seen that two POU1F1 sequences obtained from the putative hybrids differ at several points. Moreover, in comparison with POU1F1 sequences on GenBank, the fragments amplified by PG1F/PG1R primer (designed for Bos gaurus) in the putative hybrids show 99\% homology with Bos gaurus (AY770685.1). Meanwhile, those were amplified by PTF1/PTR1 primer (designed for Bos taurus) in both putative hybrids and domestic caves show 99\% homologous with Bos taurus POU1F1 corresponding fragment sequences on GenBank (AY770688.1). Therefore, it is clear that the putative hybrids inherited chromosome 1 from Bos gaurus as paternal linage. The sequences obtained in the study were submitted to GenBank with accession number KP903461 for Bos gaurus and KP903460 for Bos taurus. 
Journal of Biotechnology 15(4): 633-640, 2017

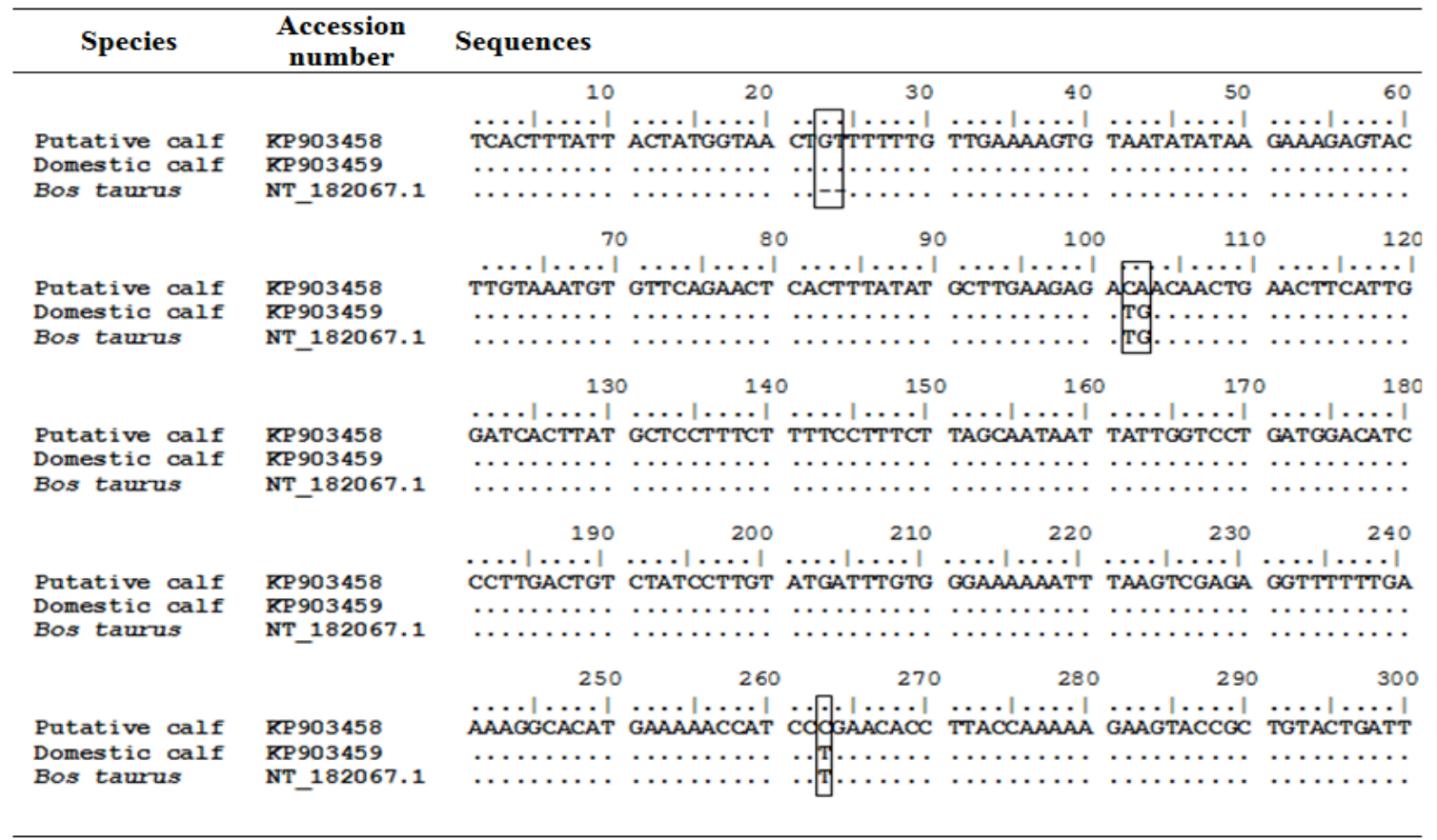

(Continued)

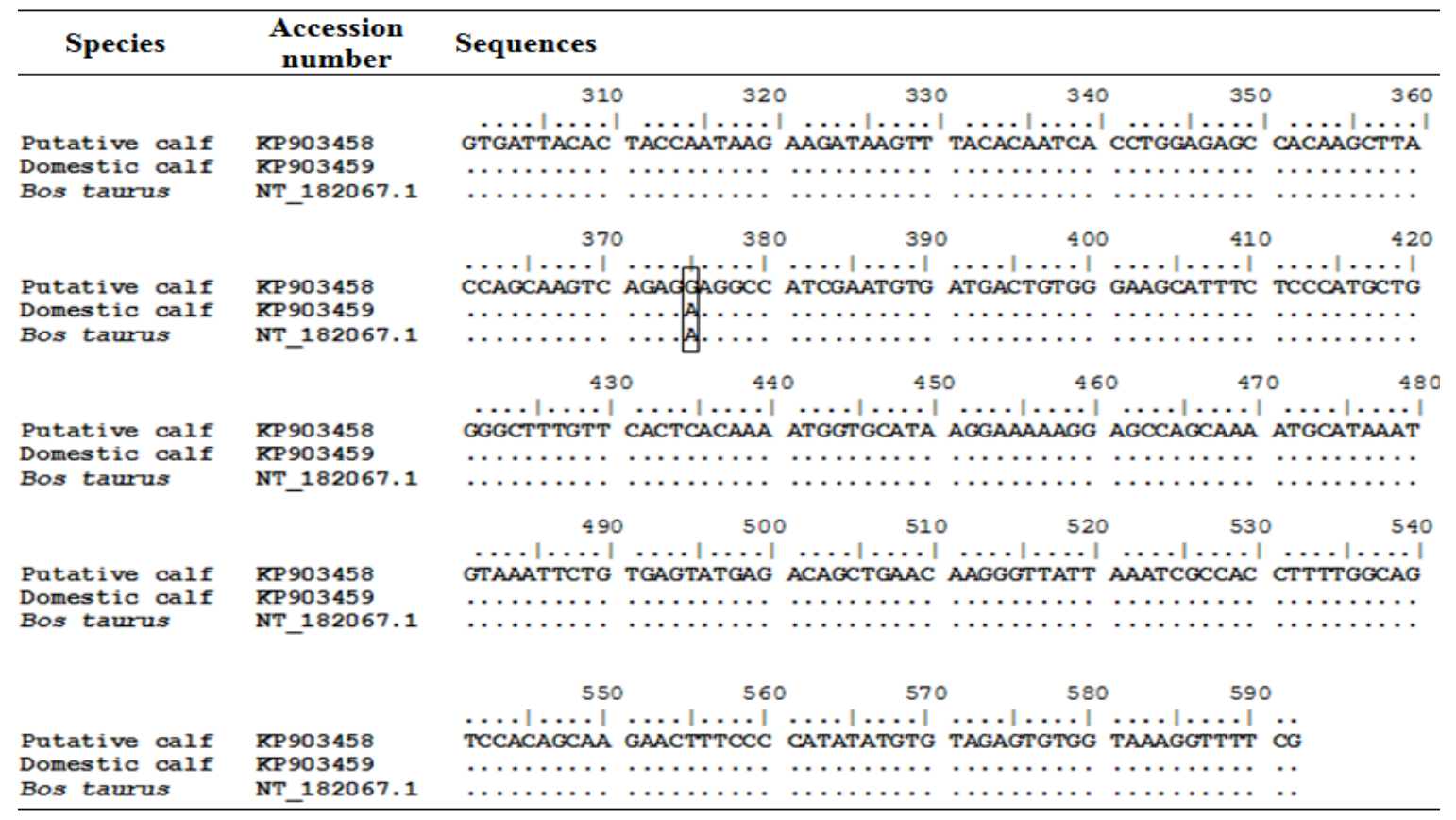

Figure 3. Alignment of ZFY partial sequence of putative hybrid, domestic calf (Bos taurus) and GenBank sequence of Bos taurus. Dots indicate identical bases and dashes indicate insertion/deletions to optimize the alignment. 


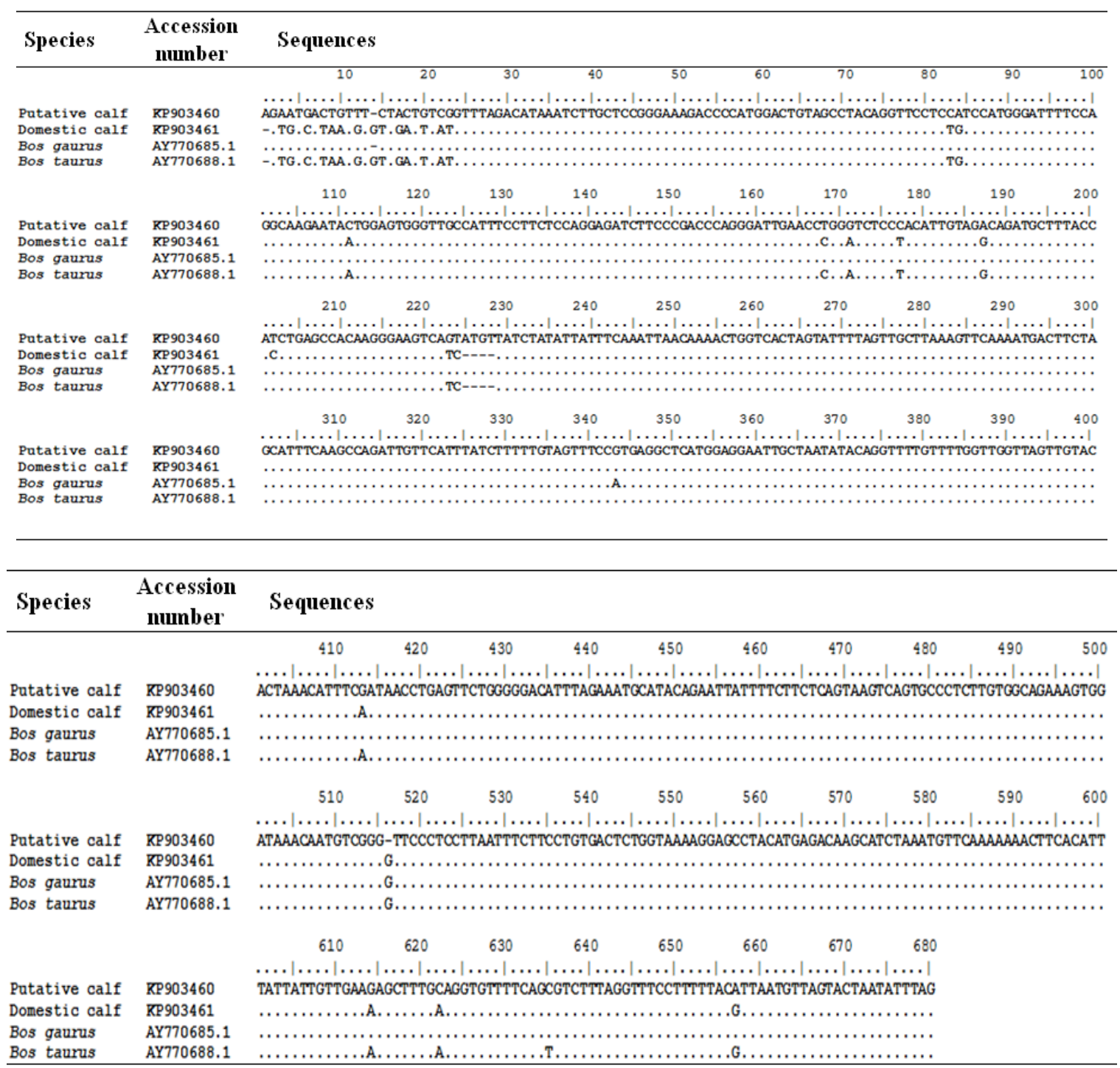

Figure 4. POU1F1 intron 5 sequence alignment of Bos gaurus primer amplification (PG), Bos taurus primer amplification (PT), GenBank's Bos gaurus sequence (AY770685.1) and Bos taurus sequence (AY770688.1). Dots indicate identical bases and dashes indicate insertions/deletions to optimize the alignment.

\section{DISCUSSION AND CONCLUSIONS}

The karyotype of putative hybrids between track-lacking wild gaur (Bos gaurus) and domestic cow (Bos taurus) was identified in a previous study. The results showed that chromosomes 1 and 2 in putative hybrids are both submetacentric and metacentric. This suggested that the putative hybrids had bands from both gaur and domestic cow (Tran Que, Pham Van Duy, 2014).
For molecular analysis, we used segment of mitochondrial Cytochrome $b$ to identify maternal species origin of the putative hybrids. Y chromosomal molecular markers including microsatellite $B M 861$ and $Z F Y$ were previously proved to be specific for gaur identification (Nguyen et al., 2007; Verkaar et al., 2003; Lawson \& Hewitt, 2002). Previous studies have proven that the POU1F1 gene is located on chromosome 1 which acts as a marker for genetic variation and growth traits (Renaville et al., 1997a; Woolard et al., 1999; 
Sadeghi et al., 2014). Because the number of Bos gaurus sequences deposited in GenBank was limited, we have used sequence variation in the POU1F1 gene between Bos gaurus (AY770685) and Bos taurus (AY770688) for the design of the convenience tests. By comparison of our data with published sequences, the authentic hybridization between Bos gaurus and Bos taurus has been verified.

The results showed the evidence that the tools we have described are suitable for detection and initially characterization of interspecific hybridization within Bovine family. Microsatellites and genes especially $P O U 1 F 1$ are proved to be appropriate markers. It can be concluded that the putative hybrids born in Phuoc Binh National Park, Vietnam are offspring of the male wild gaur and the domestic cows.

Our data, although based on a low number of samples, consistently indicate a suspected interspecific hybridization between track-lacking wild gaur and domestic cows. The methods and results we obtained have suggested being suitable for detection of interspecific hybridization in case of lacking father trace, which are essential for local breeds and preservation.

Acknowledgements: This study was financially supported by project VAST.NDP 08/16-17 (for Le Van Son) from the Vietnam Academy of Science and Technology and Lam Dong Department of Science and Technology. The authors are thankful to colleagues from Lam Dong Department of Science and Technology for their helpful assistance in sampling.

\section{REFERENCES}

Basrur PK, Moon YS (1967) Chromosomes of cattle, bison and their hybrid, the cattalo. Am J Vet Res 28 (126): 13191325.

Bona G, Paracchini R, Giordano M, Pomigliano-Richiardi P (2004) Genetic defects in GH synthesis and secretion. Eur J Endocrinol 151: S3-S9.

Chaves R, Adega F, Heslop-Harrison JS, Guedes-Pinto H, Wienberg J (2003) Complex satellite DNA reshuffling in the polymorphic $\mathrm{t}(1 ; 29)$ Robertsonian translocation and evolutionarily derived chromosomes in cattle. $J$ Chromosome Res 11(7): 641-648.
Cui X, Kimiyuki T, Shizuyo S (1998) Cloning and mapping of bovine $Z F X$ gene to the long arm of the XChromosome (Xq34) and homologous mapping of $Z F Y$ gene to the distal region of the short arm of bovine (Yp34), ovine (Yp12-p13), and caprine (Yp12-p13) Y Chromosome. Mamm Genome 9: 125-130.

Felius M (1995) Cattle breed, an encyclopedia. Doetinchem Press, Netherlands

Forsdyke DR (2000) Haldane's rule: Hybrid sterility affects the homogametic sex first because sexual differentiation is on the path to species differentiation. $J$ Theor Biol 204: 443-452.

Hall TA (1999) Bioedit: a user-friendly biological sequence alignment editor and analysis program for Windows 95/98/NT. Nucleic Acid Symp Ser 41:95-98.

Hassanin A, Ropiquet A, Cornette R, Trainer M, Pferrer P, Candegabe P, Lemaire M (2006) Has the kouprey (Bos sauveli; Urbain, 1937) been domesticated in Cambodia? $C$ R Biol 329(2):124-135.

Kakampuy W, Tanomtong A, Chaveerach A, Sangpakme W (2007) New Robertsonian translocation chromosomes in captive Thai Gaur (Bos gaurus readei). Pak J Biol Sci 10(13): 2185-2191.

Lawson LJ, Hewitt GM (2002)

Comparison of substitution rates in ZFX and ZFY introns

of sheep and goat related species supports thehypothesis of male-biased mutation rates. J Mol Evol 54 (1): 54-61.

Mamat-Hamidi K, Idris I, Hilmi M (2009) Karyotype of Malayan Gaur (Bos gaurus hubbacki), Sahiwal-Friesian Cattle and Gaur x Cattle Hybrid Backcrosses. Pak J Biol Sci 12(12): 896-901.

Mamat-Hamidi K, Hilmi M, Idris I, Di Berardino D, Iannuzzi L (2012) Chromosome evolution of the Malayan gaur (Bos gaurus hubbacki). Caryologia 65(10): 34-39.

Poloumienko A (2004) Cloning and comparative analysis of the bovine, porcine and equine sex chromosome genes ZFX and ZFY. Genome 47(1): 74-83.

Renaville R, Gengler N, Vrech E,. Prandi A, Massart S, Corradini C, Bertozzi C, Mortiaux F, Burny A, Portetelle D (1997) PIT-1 gene polymorphism, milk yield, and conformation traits for Italian Holstein-Friesian Bulls. $J$ Dairy Sci 80 (12): 3431-3438.

Sadeghi M, Jalil-Sarghale A, Moradi-Shahrbabak M (2014) Associations of POU1F1 gene polymorphisms and protein structure changes with growth traits and blood metabolites in two Iranian sheep breeds. J Genet 93(3): 831-835.

Sambrook J, Fritsch EF, Maniatis T (1989) Molecular cloning. A laboratory manual. $2^{\text {nd }}$ edition. Cold spring Harbor Laboratory Press, Cold Spring Harbor, N.Y. 
Tran Que, Pham Van Duy (2014) Determination of hybrid individuals between domestic female cow (Bos taurus) and wild male gaur (Bos gaurus) in National park of Phuoc Binh- adjointive forests of Lam Dong- Ninh Thuan- Khanh Hoa. International conference: cooperation between science, technology and sustainable development in agriculture of Lam Dong provine-Tay Nguyen), 81:87.

Nguyen TT, Genini S, Bui LC, Voegeli P, Stranzinger G, Renard JP, Nguyen BX (2007) Genomic conservation of cattle microsatellite loci in wild gaur (Bos gaurus) and current genetic status of this species in Vietnam. BMC Genet 8:77.

Verkaar ELC, Vervaecke H, Roden C, Romeo ML, Barwengen MV, Susilawati L, Nijman IJ, Lenstra JA (2003) Paternally inherited makers in Bovine hybrid populations. Heredity 91: 565-569.

Woolard J, Tuggle CK, Ponce de Leon FA (1999) Rapid Communication: Localization of POU1F1 to bovine, ovine, and caprine 1q21-22. J Anim Sci 78: 242-243.

\title{
NGHIÊN CỨU GIÁM ĐỊNH CON LAI GIŨ̉A BÒ TÓT VÀ BÒ NHÀ TẠI VƯờN QUỐC GIA PHƯỚC BİNH, VIẸTT NAM
}

\author{
Lê Hoàng Đức ${ }^{1,2}$, Phạm Thanh Tùng ${ }^{1,2}$, Nguyễn Trung Nam ${ }^{1,2}$, Chu Hoàng Hà ${ }^{1,2}$, Lê Xuân Thám ${ }^{3}$, Lê \\ Văn Sơn ${ }^{1,2}$
}

${ }^{1}$ Viện Công nghệ sinh học, Viện Hàn lâm Khoa học và Công nghệ Việt Nam

${ }^{2}$ Học viện Khoa học và Công nghệ, Viện Hàn lâm Khoa học và Công nghệ Việt Nam

${ }^{3}$ Sở Khoa học và Công nghệ tỉnh Lâm Đồng

\section{TÓM TĂT}

Hiện tượng lai khác loài giữa loài hoang dã và gia súc thuần hóa diễn ra trong tự nhiên do sự chồng lấn sinh cảnh giữa động vật hoang dã và khu chăn thả gia súc của con người. Do mất đi sinh cảnh sống, số lượng bò tót tại Việt Nam đã bị suy giảm nghiêm trọng. Năm 2009, một con bò tót (Bos gaurus) đã xuất hiện kết hợp với các con bò cái nhà (Bos taurus) tại Vườn quốc gia Phước Bình, giáp ranh giữa tỉnh Lâm Đồng và Ninh Thuận. Một số con bò nghi lai đã được sinh ra với các đặc điểm giống với bò tót. Nghiên cứu trước đó cho thấy, các con bò nghi lai có bộ nhiễm sắc thể $2 \mathrm{n}=58$ và có cặp nhiễm sắc thể 28 và 29 không tương đồng. Trong bài báo này, chúng tôi trình bày các kết quả xác định các con nghi lai giữa bò tót và bò nhà thông qua phân tích các trình tự các đoạn gen Cytochrome $b, Z F Y, P O U 1 F 1$ và các chỉ thị SSR. Phân tích trình tự Cytochrome $b$ cho thấy các con nghi lai có cùng quan hệ theo dòng mẹ với độ tương đồng nucleotide là $100 \%$. Chỉ thị $B M 861$ và trình tự vùng gen $Z F Y$ trên nhiễm sắc thể Y cho phép phân biệt các con đực nghi lai và con đực nhà. Đặc biệt, phân tích trình tự vùng gen $P O U 1 F 1$ trên nhiễm sắc thể số 1 cho phép phân biệt giữa các con nghi lai. Các kết quả nghiên cứu đã khẳng định kết quả phân tích nhiễm sắc thể và cho phép phân biệt con lai giữa bò tót và bò nhà trong trường hợp không thu được mẫu của con bò tót bố.

Tù̀ khóa: Con lai khác loài, chỉ thị phân tử, dòng bố, dòng mẹ 